\title{
Distribution, habitat selection and behaviour of the East Coast Akalat Sheppardia gunningi sokokensis in Kenya and Tanzania
}

\author{
ERWIN NEMETH and LEON BENNUN
}

\section{Summary}

This study investigated the distribution and habitat selection of the globally threatened East Coast Akalat Sheppardia gunningi sokokensis in Arabuko-Sokoke Forest, the Shimba Hills (both Kenya) and the lowland East Usambara Mountains (Tanzania). The species is more abundant than originally thought. In Arabuko-Sokoke Forest, akalats occur in two of the main vegetation types, and an estimated 7,500-9,000 territories represent one of the largest populations of this species in the world. Akalats occurred at similar densities to those in Arabuko-Sokoke (c. o.5 pairs/ha) in parts of Shimba Hills and East Usambaras, but were more patchily distributed. This akalat prefers areas where the undergrowth is partially open with large amounts of dead wood. It forages on or near the ground. In Arabuko-Sokoke Forest, areas where akalats were present had a higher abundance of ground-dwelling arthropods than areas where they were not. The akalat inhabits both primary forest and regenerated areas that have been selectively logged probably more than 20 years ago. Despite its relatively high densities where it occurs, this species (like other threatened birds in the East African coastal forests) is very patchily distributed and dependent on a habitat that is now highly fragmented and under considerable human pressure. The conservation situation in Arabuko-Sokoke gives cause for concern, and the destructive effects of a large elephant population threaten the forests of the Shimba Hills. The conservation status of the lowland Usambara Mountains is probably better and more stable.

\section{Introduction}

The East Coast Akalat Sheppardia gunningi (Turdidae) is classed as globally Vulnerable (Collar et al. 1994) and the subspecies sokokensis as regionally Endangered in Kenya and Tanzania (Bennun and Njoroge 1996). The species is restricted to forests along the eastern African coast and in Malawi, with a scattered and patchy distribution. Three subspecies are known: nominate gunningi in the south of Mozambique, bensoni from Malawi, and - the focus of this study - sokokensis from several forests in Tanzania and Kenya (Keith et al. 1992). A population recently discovered in the Nguu Mountains, Tanzania is not yet racially assigned and may represent a new subspecies (Seddon et al. 1999a).

The subspecies sokokensis has been recorded in Kenya in forests of the lower Tana River, the Arabuko-Sokoke Forest, the Shimba Hills and a small forest patch 


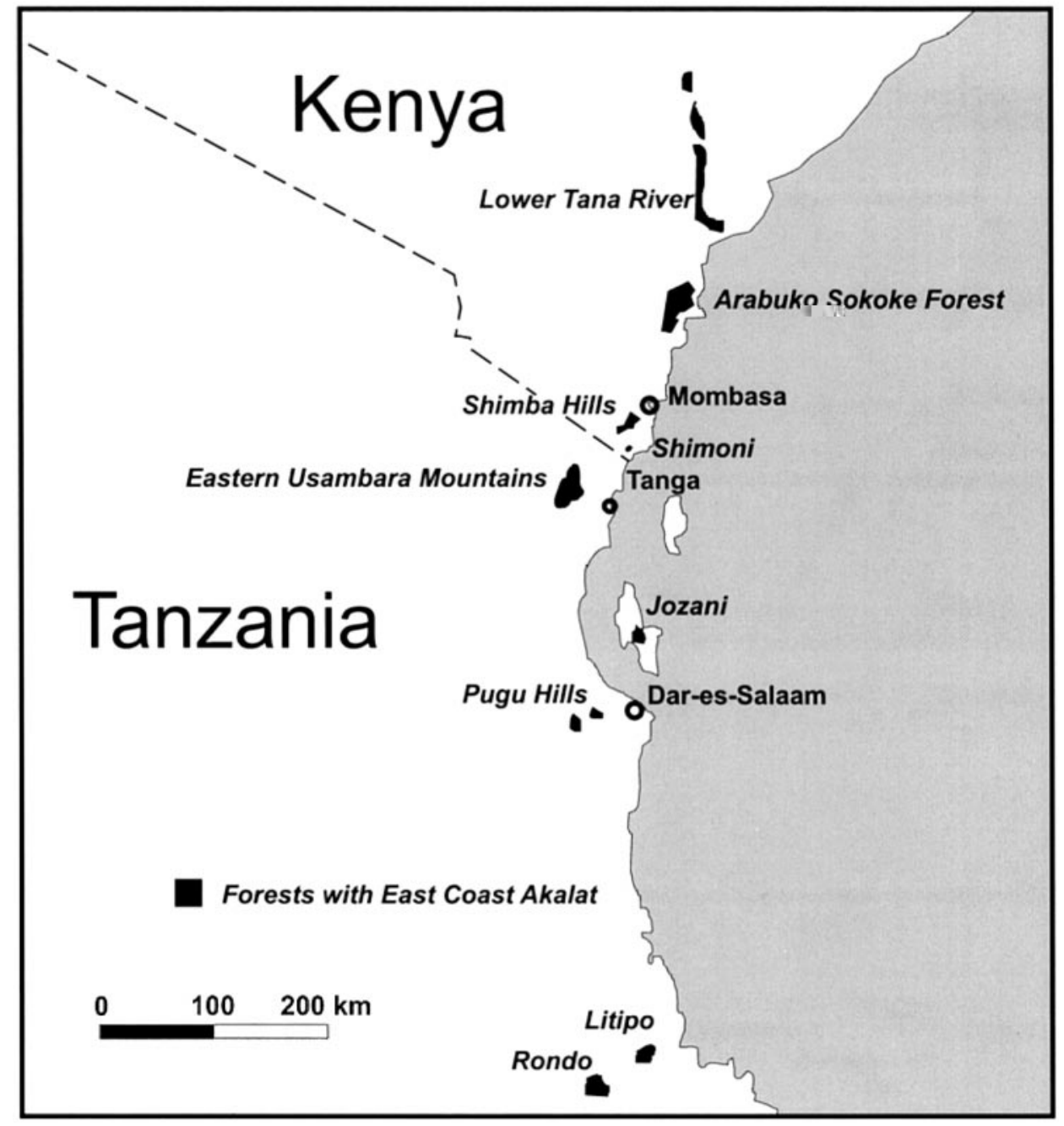

Figure 1. Study areas and other forests where the subspecies Sheppardia gunningi sokokensis has been recorded.

in Shimoni (Britton 1980, Zimmerman et al. 1996). There are recent records only from Arabuko-Sokoke and the Shimba Hills (Bennun and Waiyaki 1992a,b). In Tanzania, the species is known from the lowland parts of the East Usambara Mountains, the Nguu Mountains, the Pugu Hills, the Chitoa and Litipo Forest Reserves, the Rondo Plateau and Jozani Forest on Zanzibar (Archer et al. 1991, Holsten et al. 1991, Collar et al. 1994, Hipkiss et al. 1994, Seddon et al. 1999a,b; Figure 1).

Very little has been recorded about this species's ecology, numbers, habitat choice or behaviour. East Coast Akalats inhabit the lower forest strata and have been seen flycatching for insects from a perch and searching for food on the ground (Keith et al. 1992). In the south of Mozambique, the species has been 
found feeding in association with Red-capped Robin-chats Cossypha natalensis and Eastern Bearded Scrub-robins Cercotrichas quadrivirgata. In coastal forests such as Arabuko-Sokoke Forest it has been said to prefer moister sites (Britton and Zimmerman 1979) and surveys found it to be patchily distributed in one of three forest types, i.e. the mixed forest (Bennun and Waiyaki 1992a).

The main aim of this study was to investigate the distribution, habitat selection and behaviour of this skulking member of the thrush family.

\section{Methods}

\section{Study sites}

Fieldwork lasted from late November 1995 until the end of February 1996. The main study site was the Arabuko-Sokoke Forest in Kenya. From 21 to 27 January 1996 akalats were also located, and habitat measurements taken, in the Shimba Hills National Reserve (Kenya). For the same reason the East Usambara lowland forests (Tanzania, see Figure 1) were visited from 22 January to 7 February 1995. Additionally, searches were made for this species, without success, in Buda and Mrima Forests in south coastal Kenya.

\section{Arabuko-Sokoke Forest}

The Arabuko-Sokoke Forest Reserve $\left(3^{\circ} 11^{\prime}-3^{\circ} 30^{\prime} \mathrm{S}\right.$ and $39^{\circ} 47^{\prime}-40^{\circ} \mathrm{O}^{\prime}$ E) includes the largest remaining area (about $382 \mathrm{~km}^{2}$ ) of indigenous coastal forest in East Africa (Bennun and Njoroge 1999, Mlingwa et al. in press). The mean annual rainfall is between 600 and $1100 \mathrm{~mm}$, with a gradient from the wetter south and east to the relatively dry north-west. Arabuko-Sokoke contains three very different forest types (Blackett 1994a, Bennun and Njoroge 1999; see Figure 1): (1) mixed forest $\left(70 \mathrm{~km}^{2}\right)$ in the east, on grey sands. This relatively dense, tall and undifferentiated forest includes a diversity of tree species, among them Combretum schumannii, Drypetes reticulata, Afzelia quanzensis, Dialium orientale, Hymenaea verrucosa and Manilkara sansibarensis; (2) Brachystegia woodland $\left(77 \mathrm{~km}^{2}\right)$ on white soil. This relatively open habitat, dominated by Brachystegia spiciformis, runs in a strip through the approximate centre of the forest; (3) to the west, on red Magarini sands, is Cynometra forest and thicket, dominated by Cynometra webberi with Manilkara sulcata, Oldfieldia somalensis and (formerly) Brachylaena huillensis. In the north and south of this zone are two areas of relatively tall Cynometra forest, with a canopy height of up to $20 \mathrm{~m}$, covering $33 \mathrm{~km}^{2}$ and $66 \mathrm{~km}^{2}$ respectively. Between these is a lower, scrubbier formation of intermediate Cynometra $\left(113 \mathrm{~km}^{2}\right)$ with a canopy height of 7-8 $\mathrm{m}$. The dry north-western part of the reserve is covered by low (up to $5 \mathrm{~m}$ ), dense Cynometra thicket $\left(23 \mathrm{~km}^{2}\right.$ ). Many parts of the forest have been logged in the past, which has changed the tree species composition and forest structure (Fanshawe 1995).

Five other globally threatened bird species occur in the forest. These are Sokoke Scops Owl Otus ireneae, Sokoke Pipit Anthus sokokensis, Spotted Ground Thrush Zoothera guttata, Amani Sunbird Anthreptes palidigaster and Clarke's Weaver Ploceus golandi (Collar et al. 1994, Bennun and Njoroge 1999). The owl and the weaver are each known from only one other site. 
Shimba Hills, Mkongani and Maluganji Forests

The forests of Shimba Hills National Reserve and the adjacent Mkongani Forests $\left(4^{\circ} \mathrm{O9^{ \prime }}-4^{\circ} 21^{\prime} \mathrm{S}\right.$ and $\left.39^{\circ} 16^{\prime}-39^{\circ} 30^{\prime} \mathrm{E}\right)$ are located in south-eastern Kenya some 30 $\mathrm{km}$ south-west of Mombasa. The area comprises a dissected plateau of elevation 120-450 m. The small Maluganji Forest Reserve $\left(17 \mathrm{~km}^{2}\right)$ lies $5 \mathrm{~km}$ north of Shimba Hills. The annual rainfall is around $1240 \mathrm{~mm}$ (Collar and Stuart 1988). The vegetation of Shimba Hills National Reserve $\left(192 \mathrm{~km}^{2}\right)$, Mkongani North (11 $\mathrm{km}^{2}$ ) and Mkongani West $\left(14 \mathrm{~km}^{2}\right)$ is a mosaic of forest $\left(44 \%\right.$ or $\left.95 \mathrm{~km}^{2}\right)$, scrub formations $\left(40 \%\right.$ or $87 \mathrm{~km}^{2}$ ) and grassland (12\% or $27 \mathrm{~km}^{2}$ : Blackett $\left.1994 \mathrm{~b}\right)$. At least three globally threatened bird species occur in these forests: Sokoke Pipit Anthus sokokensis, East Coast Akalat Sheppardia gunningi and Spotted Groundthrush Zoothera guttata (Bennun and Waiyaki 1992b). Like other coastal forests, these areas have been heavily exploited for timber during the past 50 years.

Shimba Hills and the adjacent reserves hold a large elephant population, with more than 600 individuals. This complicates fieldwork in the area, and only easily accessible sectors could be investigated. Habitat measurements were taken in Makadara, Longomagandi and Mkongani North Forest. A short visit was made to Maluganji Forest. Longomagandi and Makadara represent the Milicia forest type, Manilkara-Combretum forest dominates in Mkongani, and the much drier Maluganji is (or was) mainly covered by Cynometra-Brachylaena woodland (Davies 1993, Blackett 1994b).

\section{Lowland East Usambara Mountains}

The East Usambara Mountains lie in northeastern Tanzania $\left(4^{\circ} 48^{\prime}-5^{\circ} 13^{\prime} \mathrm{S}\right.$ and $\left.38^{\circ} 32^{\prime}-38^{\circ} 48^{\prime} \mathrm{E}\right), 40 \mathrm{~km}$ inland from the coast. They rise sharply to over $1,000 \mathrm{~m}$ with the highest peak at 1,506 $\mathrm{m}$. Annual rainfall is about 2,000 $\mathrm{mm}$ and the area constitutes an important watershed for the Tanga region (Hamilton and Bensted-Smith 1989). The total forest cover is $265 \mathrm{~km}^{2}, 224 \mathrm{~km}^{2}$ of it lowland forest below $800 \mathrm{~m}$ and $125 \mathrm{~km}^{2}$ below $400 \mathrm{~m}$ (Cambridge Tanzania Rainforest Project, 1994). In the lowland parts of the East Usambaras six globally threatened bird species have been recorded (CTRP 1994, Evans et al., 1994, Evans 1997). These are Usambara Eagle Owl Bubo vosseleri, Sokoke Scops Owl Otus ireneae, East Coast Akalat Sheppardia gunningi, Swynnerton's Forest Robin Swynnertonia swynnertoni, Banded Green Sunbird Anthreptes rectirostris and Amani Sunbird Anthreptes pallidigaster.

Kambai, Kwamgumi and Segoma Forest Reserves were visited, all areas that were also surveyed by an expedition team in 1992-1993 (CTRP 1994). All sites support dense, semi-deciduous forest.

\section{Mist-netting}

Forty-two East Coast Akalats were colour-ringed at two sites in Arabuko-Sokoke, the Nature Trail (in mixed forest) and Komani (in Cynometra) (Figure 2). In most cases the birds were lured into the nets with a tape-recorded song. All trapped birds were measured and ringed with colour rings and East Africa Natural His- 
tory Society metal rings. To estimate territory size, 15 colour-ringed birds (five at the Nature Trail and 10 at Komani) were observed over 12 days.

\section{Point counts}

These counts were used to map out the overall distribution of the species in the forest. A large part of the forest was covered using a vehicle. Every $500 \mathrm{~m} \mathrm{a}$ five-minute long recording of the East Coast Akalat was played. An exception were areas within the Brachystegia woodland, where there were obviously no akalats; here the distance between counting points was extended to $1,000 \mathrm{~m}$. Every bird that reacted was recorded on a map. Birds were counted from early morning until 1ohoo, since bird activity appeared to decrease strongly during the hotter hours of the day. All forest roads in Figure 2 were visited.

\section{Transect counts}

Transect counts were used to estimate population densities. Along 11 straight or almost straight transects, trails or old roads, ranging from 500 to $1300 \mathrm{~m}$ long, all singing East Coast Akalats were counted and located as exactly as possible (Figure 2, Table 1). Synchronously singing birds were noted and every attempt was made to exclude double counts. Every $100 \mathrm{~m}$ (or if necessary every $50 \mathrm{~m}$ ) a tape-recording of the song or call of the species was played and the reactions and locations of the birds recorded. All counts were conducted before 1 ohoo or after 17 hoo. From the observed reaction of colour-ringed birds to playback, the maximum effective distance for the transect counts was estimated to be $100 \mathrm{~m}$ either side of the transects. The average count across transects for each area was calculated to estimate the population density. For transects that were counted more than once, the highest count was taken.

\section{Habitat measurements}

In Arabuko-Sokoke Forest (Figure 2) and the Shimba Hills habitat variables were measured within akalat territories and in areas without akalats. In the East Usambaras measurements were made only in areas with akalats, because of lack of time. In all, 71 plots were measured with 47 territory plots and 24 non-territory plots (Table 2).

In territory plots an approximate "centre" for the territories was based on singing posts and flight directions after playback. For habitat measurements, a circle $30 \mathrm{~m}$ in diameter centred on this point was used. Along the diameters of this circle in the north-south and east-west directions, the following variables were measured every $5 \mathrm{~m}$ :

Density of vegetation at $0.5,1,1.5$ and $2 \mathrm{~m}$ above the ground: at the respective heights, an A4-sized white board was held perpendicular to an observer at $5 \mathrm{~m}$ distance. The observer estimated the percentage of the board covered by vegetation.

Shrub height: with a $3 \mathrm{~m}$-long stick, marked at $50 \mathrm{~cm}$ intervals, the height of the understorey shrubs was measured. 
Number of trees $>15 \mathrm{~cm}$ dbh: all trees with a dbh $>15 \mathrm{~cm}$ and within $5 \mathrm{~m}$ of the transect line were recorded.

Number of dead fallen stems: within $5 \mathrm{~m}$ of the transect line, all dead fallen stems $>10 \mathrm{~cm}$ diameter and longer than $30 \mathrm{~cm}$ were counted.

Canopy openness: this was defined as $100 \%$ less the percentage canopy cover and was estimated every $5 \mathrm{~m}$ along the transect line by looking upwards through a cardboard tube.

Tree height: two observers estimated the height of the highest tree in each plot and the average was taken for analysis.

In Arabuko-Sokoke, all no-akalat plots were located in the northern Cynometra (as akalats appeared to be distributed throughout the southern sector) or in the southern mixed forest (in a region of higher human disturbance). Here and in the Shimba Hills, difficulty of access prevented a completely random design being adopted. However, all plots were located at least $100 \mathrm{~m}$ away from roads (to avoid possible edge effects) and spaced at least $100 \mathrm{~m}$ apart. Areas where nonakalat plots were placed were also chosen to be as close to akalat-inhabited areas as possible (with the exception of Longomagandi in the Shimba Hills, where akalats were present in former years).

\section{Observations}

Over nine mornings, three nests where parents were feeding were watched. In two cases the young subsequently disappeared without any trace of the predator. In the third nest the young left the nest early and were not found again. On 28 mornings or evenings about 70 person-hours were spent making observations of at least eight different foraging birds. Because of the secretive nature of the species this resulted in only 15 foraging observations. Given the lack of information on the behaviour of this species, we report on these few foraging observations here.

\section{Pitfall traps}

"Mnasi", a local palm wine, in plastic jars was used to catch ground living arthropods. At each of the five sites (Figure 2) 40 traps were placed, evenly distributed along a $1-\mathrm{km}$-long line except in the southern part of the mixed forest where two 500-m-long lines with 20 traps each were used. Trap contents were collected after 24 hours.

\section{Statistics}

The software package SPSS was used for statistical analyses. All non-parametric tests were calculated according to Siegel and Castellan (1988).

\section{Results and Discussion}

Distribution and abundance of akalats in Arabuko-Sokoke Forest

Figure 2 shows the extrapolated distribution based on point counts of the East Coast Akalat in the Arabuko-Sokoke Forest. The birds were found only in the 


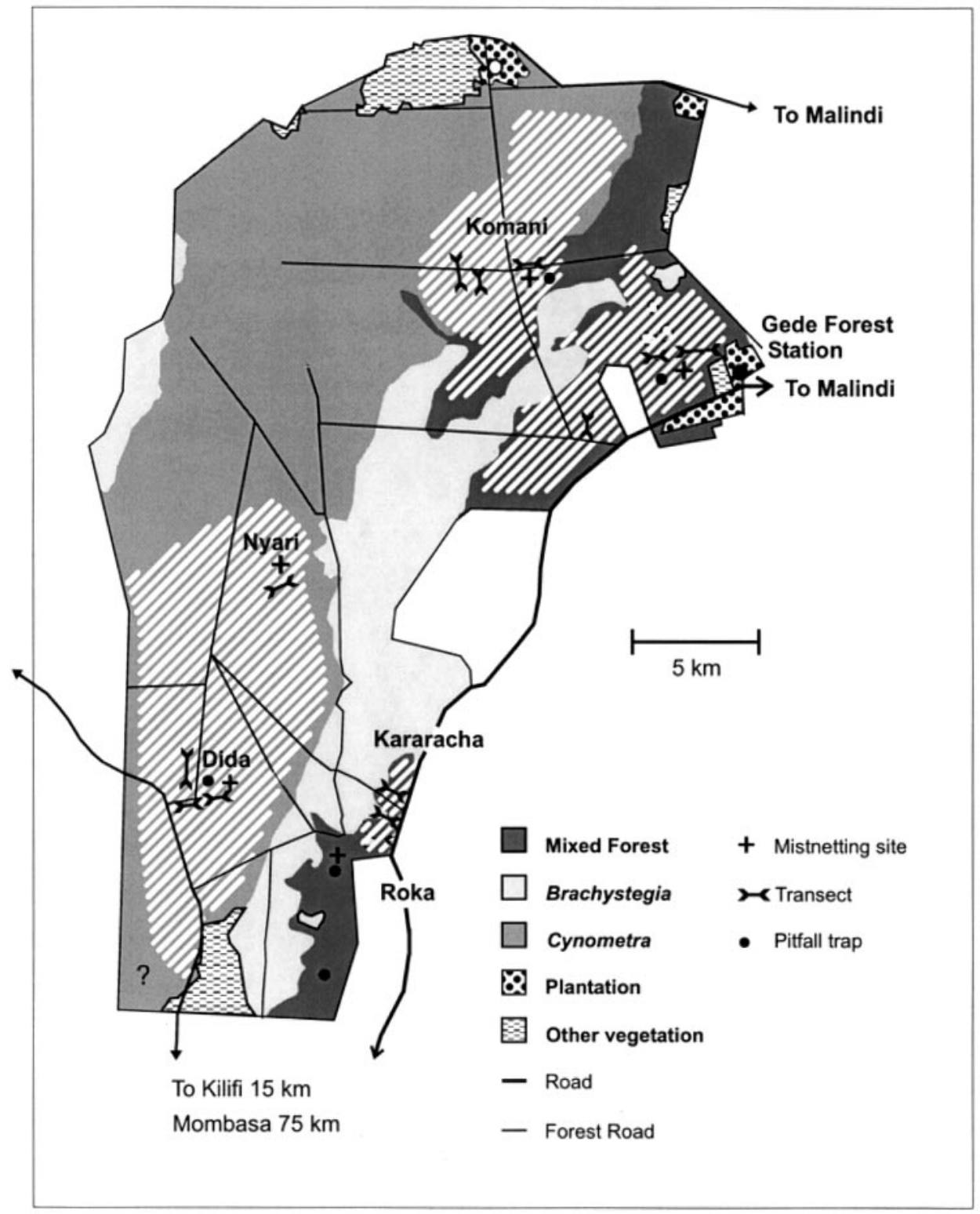

Figure 2. Arabuko-Sokoke Forest: main vegetation types and study locations. Hatched areas represent parts where East Coast Akalats were present.

northern part of the mixed forest and in the relatively tall north-eastern and south-western parts of the Cynometra forest.

Territory mapping showed that at the Nature Trail site akalats had a scattered distribution with territories of about 100-200 m diameter. At Komani birds were more evenly distributed and at a higher density, with a territory diameter of around $70 \mathrm{~m}$ (see also Matiku et al. in press). 
Table 1. Estimate of the number of territories of the East Coast Akalat in Arabuko-Sokoke Forest based on transect counts

\begin{tabular}{lccccc}
\hline & $\begin{array}{c}\text { Transect } \\
\text { length }(\mathrm{km})\end{array}$ & Transects $(n)$ & Akalats/ha & Area (ha) $)^{\mathrm{a}}$ & Birds $(n)$ \\
\hline Mixed forest & 3.3 & 4 & 0.23 & $4,000^{\mathrm{a}}$ & 920 \\
Cynometra north & 2.9 & 3 & 0.37 & 3,300 & 1,221 \\
Cynometra south & 4.15 & 4 & 0.81 & 6,600 & 5,346 \\
Total & 10.35 & 11 & 0.47 & 13,900 & 7,487 \\
\hline
\end{tabular}

${ }^{a}$ In mixed forest the species was only present in the northern parts, over an estimated area of 40 $\mathrm{km}^{2}$. The area sizes of the Cynometra woodland are taken from Kelsey and Langton (1984).

Densities derived from transect counts were used to calculate overall population size. Birds might also have occurred in the areas that were not covered. Assuming that they did not, and estimating a detection distance of $100 \mathrm{~m}$ for transect counts, the total number of territories in Arabuko-Sokoke Forest should be about 7,500 across the three areas where the birds were found to occur (Table 1). Using maximum territory diameters as a measure of effective transect width, Matiku et al. (in press) obtained a slightly higher estimate, of around 9,00o birds.

\section{Abundance in Shimba Hills and the East Usambara Mountains}

Since much less time was spent at these sites it was not possible to provide such an accurate estimate of population sizes. Singing activity was very low in both places (only one spontaneously singing akalat was heard in the Usambaras), but the birds reacted reliably to song playback. In Kwamgumi Forest Reserve, East Usambaras, six birds over $700 \mathrm{~m}$ were counted, giving an estimated density of c. 0.5 territories/ha. This is as high as in the northern Cynometra forest of Arabuko-Sokoke. In Kambai Forest Reserve the species was very sparsely distributed (cf. Evans et al. 1994); only one bird was found on a transect $2 \mathrm{~km}$ long. In Mkongani Forest, Shimba Hills, six birds/800 m or 0.4 territories/ha were counted. No akalats were found in Longomagandi Forest, nor in Maluganji Forest. The habitat at both these sites had been severely disturbed by elephants (see below).

The forests of the Shimba Hills cover about $95 \mathrm{~km}^{2}$. Akalats were only found in the south-western part of the reserve. Since we have no exact distribution data we can only guess that about half of the area is suitable for akalats. With the density data from Mkongani Forest this gives an estimate of about 2,00o territories.

There is about $97 \mathrm{~km}^{2}$ of lowland forest below $400 \mathrm{~m}$ in the lowland East Usambaras (Evans 1997) where East Coast Akalats may occur. Using the maximum density found in Kwamgumi Forest, this would give a population estimate of nearly 5,000 territories. Evans (1997) heard akalats more often in Manga and Longuza (north) forests than in Kwamgumi, but the survey dates suggest that this is likely to have been a seasonal effect. Indeed, Evans's data for Manga and Longuza suggest similar densities to Kwamgumi, 0.5 birds/ha. On the other hand, densities in Kambai Forest Reserve are much lower (Evans et al. 1994, this study) and the species is absent from some forests, such as Kisiwani (Evans 1997), so it is unlikely that the total numbers are this high. Despite intensive effort, 
Cordeiro and Githiru (2000) failed to find the species in four lowland forest patches (containing a mixture of Brachylaena woodland and mixed dry forest) to the north of the patches surveyed by Evans et al. (1994).

\section{Habitat selection}

At all study sites the vegetation density measurements at different heights were highly correlated (the lowest $r_{\mathrm{s}}=0.69, P<0.001$ ). For easier interpretation of the results we decided to combine these into one new density variable which is calculated as the average of the four density measurements. Since the three forests differ greatly in their botanical character, we made separate comparisons for each. Many of the variables were not normally distributed, therefore we used non-parametric tests for comparison (Table 2).

For the Shimba Hills, Table 2 combines data from two different forests, Makadara and Mkongoni. Even if comparisons are made separately for the two forests, akalat territories differ significantly from non-territories in vegetation density and canopy openness (Wilcoxon-Mann-Whitney $U$-test: $P<0.05$ and $P<0.01$ each time $n_{1}=8$ and $n_{2}=4$, respectively).

The variables that show differences between plots with and without akalats themselves vary between the three forest areas. In the mixed forest of ArabukoSokoke the no-akalat plots were characterized mainly by a higher vegetation density, less dead wood and more cut stems. Apparently the differences reflect the effects of a higher intensity of wood extraction (through tree-cutting and fuelwood collection). In the no-akalat plots of the Cynometra sector, the canopy height was lower, the canopy openness higher, the number of trees higher and the amount of dead wood lower than in akalat plots. At several of the no-akalat plots, but not at any akalat plots, there were clear signs of recent extraction of wood, which explains the smaller amount of dead wood at these plots. Here, cutting was mainly for Brachylaena trees, which is a slow-growing species favoured as wood for fuel, furniture and carving. However, no more cut stems were recorded in no-akalat than akalat plots. This may be because the Cynometra sector of the forest has been exploited extensively over the past few decades.

In Shimba Hills the no-akalat plots showed a significantly lower mean vegetation density below $2 \mathrm{~m}$ and a denser canopy than the akalat plots. All no-akalat plots were within the Longomagandi Forest, an area where the East Coast Akalat was mist-netted, in relatively large numbers, three years before (Bennun and Waiyaki 1992b). The high and still-increasing elephant population seems the most probable explanation for the current absence of the birds. Evidence of understorey destruction was everywhere. In nearby Maluganji Forest Reserve the forest had largely disappeared through damage from the elephants.

If the medians of no-akalat and akalat plots are compared across all the sites, taking all the data together, the only variable that is slightly, but significantly different is the number of trees. This is higher in akalat plots (Median Present $=$ 12.75, Median ${ }_{\text {Absent }}=11$, Mann-Whitney $U$-test: $P=0.03, n=7$ ). The other variables show inconsistent patterns across the different sites, partly because of the bimodal distribution of habitat characteristics at non-territory sites. For instance, the vegetation density is very low in non-territories in the Shimba Hills forests, whereas it is very high in non-territories of the mixed forest in Arabuko-Sokoke.

The akalat's apparent sensitivity to habitat structure, and disturbance, in Ara- 


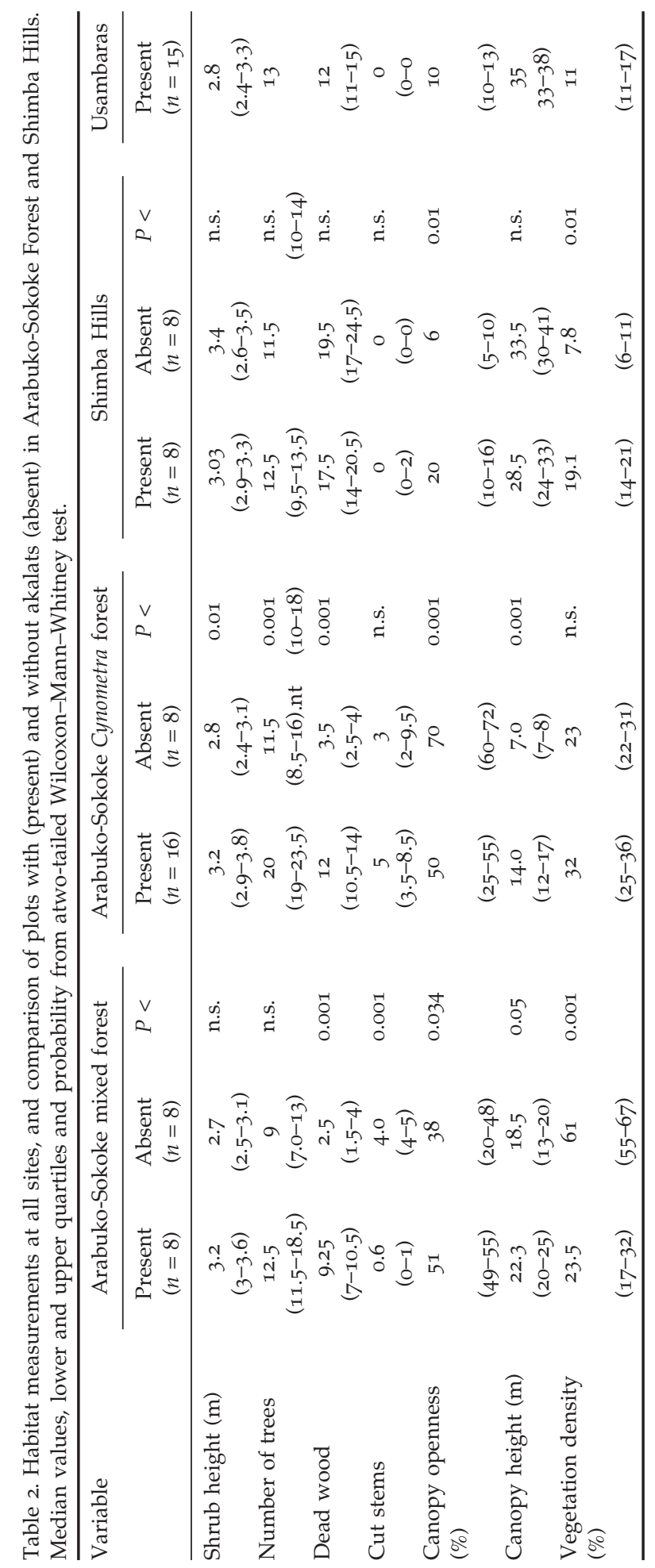


buko-Sokoke and Shimba Hills does not seem to be reflected in the East Usambaras. There, Evans (1997) and Evans et al. (1994) found the species in a range of habitats from tall, little-disturbed forest to heavily disturbed evergreen thicket and secondary growth regenerating after logging. A more detailed study is needed to resolve this puzzling discrepancy.

\section{Observations of foraging and feeding}

Foraging birds were observed on 15 occasions, 12 times taking food from the ground, twice from dead fallen wood, and once from leaves $1 \mathrm{~m}$ above the ground. On six occasions the birds were seen perched (from 0.3 to $1.5 \mathrm{~m}$ high) before they sallied to the ground. Three times they were seen hopping on the ground and turning leaves. On two occasions, two different birds were seen following, and feeding together with, a Four-toed Elephant Shrew Petrodomus tetradactylus. In one of these cases a mixed understorey bird party was feeding close by. The following food items were identified: cockroaches (4), locusts (2), spiders (2) and a caterpillar. Akalats were never seen taking berries or seeds as described by Seddon et al. (1999a) in the Nguu Mountains. The bird's diet may change seasonally; most African robins probably take some fruit at times (Oatley 1969).

Twenty-five food items were identified, fed to the young at three watched nests (E.N., pers. obs.). There were eight caterpillars, seven locusts, two spiders, two lepidopterans, three mantises, one millipede and one insect egg.

The spectrum of food items identified, both for foraging birds and provisioning adults, is probably biased by the visibility of prey items. Together with the low number of observations this could be the reason that we did not record ants as prey. These have already been documented in an East Coast Akalat stomach (Irwin 1963) and are a very likely prey of all African robins (Oatley 1969).

\section{Abundance of arthropods in Arabuko-Sokoke forest}

The highest numbers of ground-living arthropods were found in the Cynometra forest with akalats, while the lowest numbers were recorded from the areas in the mixed forest where the species was absent (Table 3). Within each forest type, significantly more ground arthropods were trapped in areas with akalats than at sites without them. Ants contributed most to the samples, but without them the differences remain significant (Table 4).

Most of the broad types of arthropods trapped are known to be eaten by the akalats (see above, and Irwin 1963, Oatley 1969). Much more study would be needed to determine prey selection in detail. One reason for the higher abundance in the territory plots could be the higher amount of dead wood. There was a significant correlation between the mean number of dead logs found in the habitat measurements and the mean number of arthropods for each site $\left(r_{\mathrm{s}}=1\right.$.0, $P<0.001, n=5)$.

\section{Conclusions}

Recent surveys have shown that this subspecies of the East Coast Akalat is relatively common in the East Usambara Mountains (Evans et al. 1994, Evans 1997). 
Table 3. Trapped arthropods in Cynometra (C) and mixed forest (MF) areas of Arabuko-Sokoke Forest. At each site 40 pitfall traps with palm wine were evenly distributed (see Figure 2 for locations)

\begin{tabular}{|c|c|c|c|c|c|}
\hline \multirow[t]{2}{*}{ Families } & \multicolumn{3}{|c|}{ Akalat present } & \multicolumn{2}{|c|}{ Akalat absent } \\
\hline & C north & C south & $\mathrm{MF}$ & C north & $\mathrm{MF}$ \\
\hline Blattoidea & 52 & 67 & 126 & 20 & 42 \\
\hline Orthoptera & 5 & 21 & 12 & 1 & 20 \\
\hline Coleoptera & 3 & 2 & 81 & 3 & 14 \\
\hline Diptera & 207 & 64 & 17 & 78 & 19 \\
\hline Lepidoptera & 1 & o & 1 & 1 & o \\
\hline Hymenoptera & 784 & 680 & 517 & 457 & 136 \\
\hline Arachnida & 4 & 8 & 12 & 10 & 1 \\
\hline Others & o & 1 & 1 & 2 & 2 \\
\hline Total & 1056 & 843 & 767 & 572 & 234 \\
\hline
\end{tabular}

Table 4. Numbers of trapped ground arthropods (with and without ants) at plots with and without Akalats in the northern Cynometra woodland and the mixed forest of Arabuko-Sokoke Forest; median values, lower and upper quartiles and probability values from a two-tailed Wilcoxon-Mann-Whitney $U$-test

\begin{tabular}{llll}
\hline Forest type & Akalats present ${ }^{\mathrm{a}}$ & Akalats absent ${ }^{\mathrm{a}}$ & $P<$ \\
\hline Cynometra north with ants & $25.5(9.75-85.8)$ & $8.6(6-25)$ & 0.01 \\
Cynometra north without ants & $15.5(7-48.5)$ & $6(5-13.8)$ & 0.01 \\
Mixed forest with ants & $11.5(7-23)$ & $6.5(3-12)$ & 0.01 \\
Mixed forestwithout ants & $9(6-19)$ & $4.5(2.75-8)$ & 0.001 \\
\hline
\end{tabular}

a In both cases $n$ is 40 .

Nonetheless, its numbers in Arabuko-Sokoke Forest were surprisingly high. This population, with an estimated size of 7,500 territories, is probably one of the largest in the world of this subspecies. For comparison, the entire Malawi population of the subspecies bensoni has been estimated at 3,000 pairs (Keith et al. 1992). However, the Nguu Mountains in Tanzania could hold an East Coast Akalat population (of as yet indeterminate race) of similar size (Seddon et al. 1999b). As the bird also occurs in a number of other sites, and as several large forests in Mozambique remain virtually unexplored (Burgess et al. 1998), the species's globally threatened status might need to be re-assessed. Seddon et al. (1999b) recommended downlisting to globally near-threatened. However, as Matiku et al. (in press) point out, the East Coast Akalat has a restricted global range (its area of occupancy is certainly less than $2,000 \mathrm{~km}^{2}$ ); its range is severely fragmented (the known localities are almost all small, and widely separated); and the area, extent and quality of habitat have shown (and will probably continue to show) a rapid decline. These features all qualify it for continued listing as a Vulnerable species (IUCN 1994). Furthermore, all the sites where the akalat occurs are under threat, and - at least in Kenya - it appears very sensitive to disturbance that alters the forest structure (Matiku 1996, this study).

The akalat was found in a wide range of different forest habitats, from the rather dry and low Cynometra forest in Arabuko-Sokoke Forest to the much moister forest, up to $40 \mathrm{~m}$ high, in the lowland Usambaras. The local distribution of the birds at the different sites suggests that birds are responding to different factors. In Arabuko-Sokoke Forest the species is missing in areas with high 
human disturbance, where there was a higher vegetation density near the ground and less dead wood. In Shimba Hills the birds have disappeared in areas where the understorey has been destroyed by elephants. These cases represent opposite extremes, both unsuitable for the species.

This local patchiness is mirrored in the patchy distribution of the species across forests. Waiyaki and Bennun (in press) failed to find akalats in fourteen coastal forests close to the Shimba Hills, although the habitat appeared to be suitable for this species in many of them (E.M. Waiyaki unpubl. data). This represents either a marked response to some habitat feature that has not yet been measured, or a tendency to local extinction (without recolonization) in forest fragments. The latter seems more probable; like a number of other coastal forest animals and plants, the East Coast Akalat appears to have a relict distribution (Mlingwa et al. in press, Burgess et al. 1998).

Foraging birds took food mainly from the ground and used perches in a rather open understorey to look out for prey. The higher densities of ground-living arthropods in plots with akalats than in those without indicate that food availability may be important in determining the species's distribution. Areas with more dead wood probably contained more potential prey. Using slightly different habitat measures, Matiku (1996) and Matiku et al. (in press) also found that dead logs were more numerous in akalat territories than elsewhere. They further found that birds showed a strong preference for areas that contained more mossy logs (numbers of dead logs and of mossy logs were positively correlated). East Coast Akalats use mossy bedding in nest construction, but the presence of mossy logs could be linked to other factors too, such as food supply.

In Arabuko-Sokoke, tree-cutting and removal of fuel wood seem to be the major threat to the habitat and thus the akalats. The species was far more abundant in the Cynometra forest (particularly the southern sector) than in the mixed forest. This area, which is also the stronghold of the Sokoke Scops Owl (Virani 1994) should be given proper attention in conservation planning.

In Shimba Hills the main problem is damage to vegetation caused by the very high elephant densities. The example of the former Maluganji Forest Reserve, which is now the Maluganji Elephant Sanctuary, is alarming. When Maluganji was visited for ornithological surveys in 1992 (Bennun and Waiyaki 1992b), damage was already severe. When visited during the present study, the Forest Reserve no longer contained any forest. Similar destruction is ongoing in Mkongani North and probably in other parts of the reserve. Urgent action is necessary to reverse this process (see also Bennun and Njoroge, 1999).

The lowland forests of the Eastern Usambaras are relatively small and fragmented. However, their status seems to be improving through the work of the East Usambara Catchment Forestry Project (EUCFP 1995, Cordeiro and Githiru 2000). Akalats here are found in a wider range of forest types and appear (though this requires confirmation) to be less affected by forest disturbance (Evans et al. 1994, Evans 1997). While many threats remain, the East Coast Akalat population here may be more secure than in either Arabuko-Sokoke or the Shimba Hills.

\section{Acknowledgements}

We thank all those who worked with in the field, in particular David Ngala, without whose knowledge of the forest and its birds the project would have been 
far less successful; Patrick Gichuki, whose organizational and bird-ringing skills proved indispensable at all field sites; Paul Matiku, Edward Waiyaki, Oliver Nasirwa and Peter Njoroge from the National Museum's Ornithology Department. We thank Anne Robertson for advice and for maps of Arabuko-Sokoke Forest, and Tansy Bliss, Ian Gordon, Mr Kirui, Mrs Barbara Simpson and Dolores Schütz for help in numerous ways in Kenya. Tom Evans, Andy Perkin and Kathleen Shurcliff provided useful information about the Usambara Mountains. Hans Winkler of the Konrad Lorenz Institute for Comparative Ethology supported E.N. with recording equipment, and made available the institute's computing facilities. Alfred Grüll of the Biological Station Illmitz in Austria lent us the mist-nets. We are grateful to Donald Blomqvist for statistical advice and to him and Sonja Kleindorfer for their comments on earlier versions of the manuscript. This project was funded by grant number 5443 of the Jubiläumsfonds of the Nationalbank of Austria to E.N. We thank the secretary of the Jubiläumsfonds for efficient handling of all funding tasks.

\section{References}

Archer, A.L., Collins, S. and Bampton, I. (1991) Report on a visit to Jozani Forest, Zanzibar. EANHS Bulletin 21: 59-66.

Bennun, L. and Njoroge, P. (eds) 1996. Birds to watch in East Africa: a preliminary Red Data list. Research Reports of the Centre for Biodiversity, National Museums of Kenya: Ornithology 23.

Bennun, L. and Njoroge, P. (1999) Important bird areas in Kenya. Nairobi: East Africa Natural History Society.

Bennun, L. and Waiyaki, E.M. (1992a) Bird communities in the Arabuko-Sokoke Forest. Research Reports of the Centre of Biodiversity, National Museums of Kenya: Ornithology 5.

Bennun, L. and Waiyaki, E.M. (1992b) Forest birds in the Shimba Hills and Maluganji: a survey. Research Reports of the Centre of Biodiversity, National Museums of Kenya: Ornitho$\log y$ 10.

Blackett, H.L. (1994a) Forest inventory report 2: Arabuko-Sokoke Forest. Nairobi: Forest Department/Kenya Indigenous Forest Conservation Programme.

Blackett, H.L. (1994b) Forest inventory report 4: Shimba Hills, Mkongani North and Mkongani West. Nairobi: Forest Department/Kenya Indigenous Forest Conservation Programme.

Britton, P.L. (1980) The birds of East Africa, their status and distribution. Nairobi: East African Natural History Society.

Britton, P.L. and Zimmerman, D.A. (1979) The avifauna of Sokoke Forest, Kenya. J. East Africa Nat. Hist. Soc. and Nat. Museum 169: 1-15.

Burgess, N.D., Clarke, G.P. and Rodgers, W.A. (1998) Coastal forests of eastern Africa: status, endemism patterns and their potential causes. J. Biol. Linn. Soc. 64: 337-367.

CTRP (Cambridge Tanzania Rainforest Project) (1994) A biological and human impact survey of the lowland forests, East Usambara Mountains, Tanzania. Cambridge, U.K.: BirdLife International (BirdLife Study Report 59.).

Collar, N.J. and Stuart, S.N. (1985) Threatened birds of Africa and related islands. The ICBP/ IUCN Red Data Book. Part 1. Third edition. Cambridge, U.K.: ICBP/IUCN.

Collar, N.J. and Stuart, S.N. (1988) Key forests for threatened birds in Africa. Cambridge, U.K.: ICBP (ICBP Monograph No.3).

Collar, N.J., Crosby, M.J. and Stattersfield, A.J (1994) Birds to watch. The world list of threatened birds. Cambridge, U.K.: Birdlife International. 
Cordeiro, N. and Githiru, M. (2000) Conservation evaluation for birds of Brachylaena woodland and mixed dry forest in northeast Tanzania. Bird Conserv. Internatn. 10: 47-65.

Davies, G. (1993) Shimba Hills, Mkongani and Maluganji Forests: biodiversity overview. Nairobi: KIFCON/NMK.

EUCFP (East Usambara Catchment Forestry Project) (1995) Project Document Phase II. Tanga: EUCFP.

Evans, D.T., Watson, L.G, Hipkiss, A.J., Kiure, J., Timmins, R.J. and Perkin, A.W. (1994) New records of Sokoke Scops Owl Bubo vosseleri and East Coast Akalat Sheppardia gunningi from Tanzania. Scopus 18: 40-47.

Evans, T.D. (1997) Records of birds from the forests of the East Usambara lowlands, Tanzania, August 1994-February 1995. Scopus 19: 92-108.

Fanshawe, J.H. 1995. The effects of selective logging on the bird community of ArabukoSokoke forest. Unpublished PhD thesis, University of Oxford, U.K.

Hamilton, A.C. and Bensted-Smith, R. (1989). Forest conservation in the East Usambara Mountains, Tanzania. Gland, Switzerland and Cambridge, U.K.: IUCN.

Hipkiss, A.J., Watson, L.G. and Evans, T.D. (1994) The Cambridge Tanzania Project 1992. Brief account of ornithological results and conservation problems. Ibis 136: 107-108.

Holsten, B., Bräunlich, A. and Huxham, H. (1991) Rondo Forest Reserve, Tanzania: an ornithological survey, including new records of the East Coast Akalat Sheppardia gunningi, the Spotted Ground Thrush Turdus fischeri, and the Rondo Green Barbet Stactolaema olivacea woodwardi. Scopus 14: 125-128.

IUCN (1994) IUCN Red List categories. Gland, Switzerland: World Conservation Union.

Irwin, M.P.S. (1963) Systematical and distributional notes on southern African birds. Durban Mus. Nov. VII(1): 1-26.

Keith S., Urban, E.K. and Fry, H.C. (1992) Birds of Africa. London: Academic Press.

Kelsey, M.G. and Langton, T.E.S. (1984) The conservation of the Arabuko-Sokoke Forest, Kenya. Report of the Arabuko-Sokoke Forest Expedition, July-August 1983. Cambridge, U.K.: ICBP.

Matiku, P.M. (1996) Habitat selection and distribution of the East Coast Akalat (Sheppardia gunningi sokokensis Van Someren 1921) in Arabuko-Sokoke Forest, Kenya. MPhil thesis, Moi University.

Matiku, P.M., Bennun, L.A. and Nemeth, E. (in press) Distribution and population size of the threatened East Coast Akalat in Arabuko-Sokoke Forest, Kenya. Ostrich.

Mlingwa, C.O.F., Waiyaki, E.M., Bennun, L.A. and Burgess N.D. (in press). Birds. In N.D. Burgess and G.P. Clarke, eds. Coastal forests in eastern Africa: biodiversity and conservation. Gland, Switzerland: IUCN.

Oatley, T.B. (1969). Observations on the food and feeding habits of some African robins (Aves: Turdinae). Ann. Natal Mus. 20(2): 293-327.

Seddon, N., Ekstrom, J.M.M., Capper, D.R., Isherwood, I.S., Muna, R., Pople, R.G., Tarimo, E. and Timothy, J (1999a) Notes on the ecology and conservation status of key bird species in Nilo and Nguu North Forest Reserves, Tanzania. Bird Conserv. Internatn. 9: $9-28$.

Seddon, N., Ekstrom, J.M.M., Capper, D.R., Isherwood, I.S., Muna, R., Pople, R.G., Tarimo, E. and Timothy, J (1999b) The importance of Nilo and Nguu North Forest Reserves for the conservation of montane forest birds in Tanzania. Biol. Conserv. 87: 59-72.

Siegel, S. and Castellan, N.J. (1988) Nonparametric statistics for the behavioral sciences. New York: McGraw Hill.

Virani, M.Z. 1994. Ecology of the endangered Sokoke Scops Owl (Otus ireneae). Unpublished MSc thesis, University of Leicester, U.K.

Waiyaki, E.M. and Bennun, L.A. (in press) The avifauna of coastal forests in southern Kenya: status and conservation. Ostrich.

Zimmerman, D.A, Turner, D.A. and Pearson, D.J. 1996. Birds of Kenya and northern Tanzania. Halfway House, South Africa: Russel Friedman Books. 


\section{ERWIN NEMETH}

Konrad Lorenz Institute for Comparative Ethology, Savoyenstrasse 1a. 1160 Vienna, Austria, e-mail: e.nemeth@klivv.oeaw.ac.at and Department of Ornithology, National Museums of Kenya, P.O. Box 40658, Nairobi, Kenya.

\section{LEON BENNUN}

Department of Ornithology, National Museums of Kenya, P.O. Box 40658, Nairobi, Kenya. 